University of Louisville

ThinkIR: The University of Louisville's Institutional Repository

Electronic Theses and Dissertations

$1-1930$

\title{
The effect of ultra-violet light upon the growth of Zea maize.
}

W. H. Clashman

University of Louisville

Follow this and additional works at: https://ir.library.louisville.edu/etd

\section{Recommended Citation}

Clashman, W. H., "The effect of ultra-violet light upon the growth of Zea maize." (1930). Electronic Theses and Dissertations. Paper 259.

https://doi.org/10.18297/etd/259

This Master's Thesis is brought to you for free and open access by ThinkIR: The University of Louisville's Institutional Repository. It has been accepted for inclusion in Electronic Theses and Dissertations by an authorized administrator of ThinkIR: The University of Louisville's Institutional Repository. This title appears here courtesy of the author, who has retained all other copyrights. For more information, please contact thinkir@louisville.edu. 


\title{
VNIVERSITY OF LOUISVILIE
}

\section{THE EF ECT OF ULTRA-VIOIET IIGHT UPON \\ THE GROWTH OF ZEA HAIZE}

\author{
A Dissertation \\ Submitted to the Faculty \\ Of the Gradiate School of the University of Louisville \\ In Partial Fulfiliment of the \\ Requirements for the Degree \\ of Master of Arts
}

Department of Biolouy

By

W. H. Clashman

1930 
1. Introduction . . . . . . . . 1

2. The Specific Problem . . . . . 8

3. Materials and Methods . . . . 10

4. Experiments. . . . . . . . 13

5. Summary and Conclusion . . . . .34

6. Bibliography . . . . . . . . . . . . . 
Dedication

In highest appreciation of the generosity and kindness of $\mathrm{Dr}$. Austin Ralph Middleton, whose sympathetic direction contributed most to this work. 
INTRODUCTION

3

s

.

, 


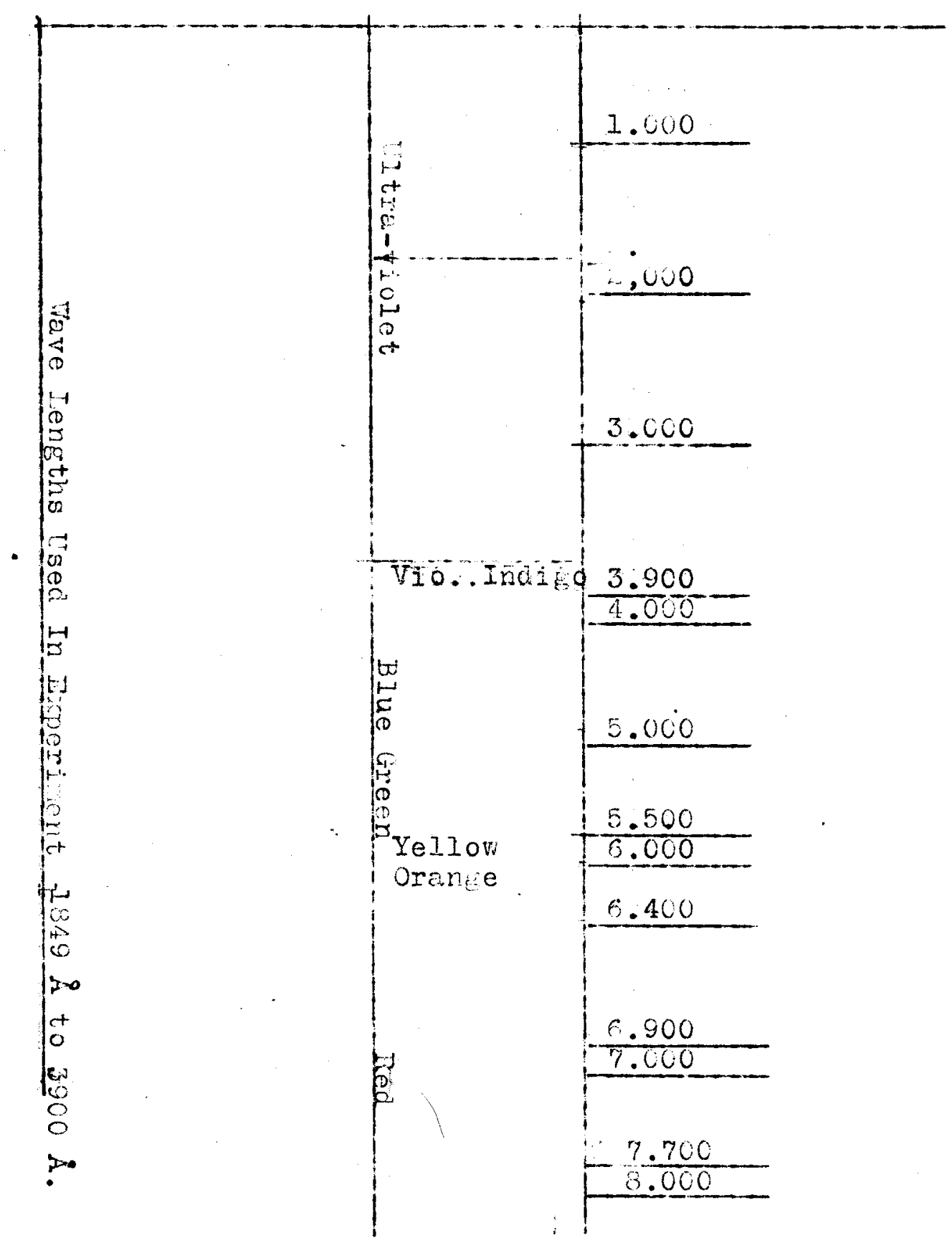

Yigure 1. Wave Aengths in Argstrow units. One Angstron $=\frac{1}{10,000,000}$ oi chillineter in length. 
Many experiments have been performed to determine the effect of ultra-violet light upon the growth of plants and animals. The conclusions reached by the experiments concerned are not constant in all cases. The more significant of these studies are here revlewed. Sheard and Johnson (17) state that the skin is the medium which separates the organism, whether it be plant or animal, from 1ts environment. The skin 18, therefore, the medium of reception of radient energy and the seat of transformation or utilization of the incident energy. No changes of a physical or chemical character are produced in the cells, tissues, or organ1sms unless there is an absorption of enerey. Protoplasm exercises a pronounced absorption of energy of short wave lengths. Other researches have demonstrated that cytoplasm absorb radiations of wave length $1600 \AA$ and the nucleus absorbs radiations of wave length $1850 \AA$.

Rose (14) in an experiment in which he treated Parameclum caudatum with ultra-violet light, found that 1t was possible to modify the living system through light 
radiations of wave lengths $1849 \AA$ to $3900 \AA$. Middleton (13) discovered that temperature produced herltable differences. Bosie and Hughes (2) discovered that ultraviolet radiation through a fluorite glass container caused cytolysis in paramecium when a certain amount of toxic s substance is formed.

Bovie (3) called attention to the fact that all life ultimately depends on photosynthetic products formed through the agency of radiation from the sun, and a mathematical expression for the relation between exposure and effect is developed. Not only are carbohydrates formed in this manner, but also photo-chemical products essential to hoalth. Rickets in children and other human ailments are compared to the etlolated condition obtained in plants deprived of light and ovidence of a fundamental relationship is prevented.

fcCrea (11) in an experiment with Digitalis Purpurea discovered that the plant develops a higher potency when subjected to the influence of ultra-violet light, also (12) that Digitalis Purpurea is benefited permanently by exposure during seeding development to 1rradiation by ultra-violet rays. Jacobs (3) tates" Ultra-violet possesses a very 
great formative effect on plants, causing the specific form of alpine flora".

Macht (9) point out that the effect of polarized light of the visible spectrum on the growth of various seedings is somewhat different from thet of non-polarized 11ght. In every experiment performed the seedlings exposed to polarized light srew better. He states further that when the seed portion of the plants were protected with tin foll, the above phenomenon did not take place. Sheard and Higgins (15) draw the following conclusions from extensive experimentation:

1. Selective irradiation of the seed modifiea the time of 1 ts germination and the rate of its subsequent growth.

2. The lesser wave lengths, in general, appear to atimulate, while the greater wave lenoths inhibit growth.

3. Wave lengths rangling from about $3200 \AA$ to 3900 A seem particularly effective in inducing growth.

4. The stimulus to most rapid geruination of seeds kept under interior diffuse daylight is an initial 1rradiation of from five to ten minutes. Longer perids of irradiation appear to have no stimulating 
effect.

They (16) also state that the development of chlorophyll is enhanced under the yellowish green, green and greenish blue regions of the spectrum.

Ell1s and Wells (5) grew plants in sunlight from which all wave lengths below $5290 \AA$ were eliminated and obtained the following results:-

1. An increased rate of elongation of the main axis and usually a greater total length, with a reduction in the number of side-shoots or branches formed.

2. A considerable decrease in thickness of stem.

3. A general curling or rolling of leaves.

4. Good development of chlorophyll as indlcated by appearance in comparison with controls in full sunlight.

5. Less compact and thinner walled cells, and a reduction in strengthening tissue.

6. Considerable delay in flowering and a reduction in the number of flowers produced.

7. Very weak fruiting and poor development of storage orjans.

3. Decrease in fresh welght and dry welsht and Increase in percentage of molsture. 
9. Considerable decrease in total carbohydrates and starch.

10. Decrease in some of the higher organic compound and an increase in soluble nitrogen compounds. 
THE SPECIFIC PROBLEM 
Llght has been recognized as one ot the greatest economic factors of life. It is only recently, however, that its effects upon organlsms have been studied sclentifically. It was observed that organisms growing in darkness or diffused sunlight were different from those exposed to the direct rays of the sun.

These observations along with the contributions of science and invention led to further investigations and experimentations. One of these important discoveries was the ultra-violet ray.

The present study is an investigation of the effects of ultra-violet ligit of wave lengths $1849 \AA$ to $3900 \AA$ upon the growth of the seedlings of zea Maize. 
TATERIALS A D IETHODS

1

. 
In order that results obtained in experimentation designed to ascertain the effect of a single enviromental factor upon the growth of plants, it is essential that the environment for both experimental and control groups be identical, except for the single factor under investigation.

For these experiments the following materials and method were used. The vessels in which the seedings grew during experimentation were glass dishes, nine inches In diameter and two inches in depth; the surface was regular and the slass was about two millimeters in thickness. Small quartz peboles were placed in the dishes to support the parafin beaver-board on which the grainsbearing the corn seedings were placed. The paraffin beaverboards were perforated with holes one half inch apart. Through these holes the roots of the seedlings were planted. Each board contilined twenty-five holes.

The glass vessels in which the seedlings were placed contained one-half inch of water. This amount was kept constant. 
Four vessels were employed, - three experimental and one control. All were subjected to the same conditions except those under experimentation. The plants were subject to diffuse sunlight and room temerature.

The source of the ultra-violet rays was a BurdickCooper-Hewitt anode tungsten cathode quartz lamp, operated at seventy-five volts. The wave length of the rays transmitted ranged frow $1849 \AA$ to $3900 \AA$. The distance of the seedings from the nercury arc was thirty inches.

The number of exposures varied with the experiments. Experiments number 1 and number $z$ each had four exposures; experiments number 3, seven exposures; and experiments number 4, number 5, and numper o each had elght exjosures.

The length of 1rradiation period for each experimental group of seedlings remained constant throughout all experiments. The seedlings of group 1 of each experiment were subjected to three ininutes exposure to the ultra: violet rays; those of group 2, to six minutes exposure; those of group 3, to ten minutes exposure. Exposures were made daily at about 8 A. M. Only one group at a time was exposed. The remaining groups 
were carefully protected from the ultra-violet rays. No exposures were made until the lamp had attained a force of 75 volts.

The above proceedure continued throughout each experiment. Accurate measurements of both the height and dlameter were taken the day following the last irradiation. This dita is in who accompanying charts. 

Experimentation was conducted with corn seedlings (zea Haize). The seed used for producing the sprouts was from selected ears fully matured in every way and of the ame type. The grains from one ear were sufficient to supply sprouts for each experiment, thus assuring as nearly as possible unfformity of vitality and heredity. Germination of the seed was under controlled conditions, at approximately 20 c. and about seventy-two hour were required for proper growth. Seedlings selected were as nearly the same size and visor as could be plcked from a large number. Probably from elght hundred to it thousand sprouts, one hundred were selected for the purpose of each experiment.

Experiment 1.

For this and each succeeding experiment, the sprouts selected were about flve mlllimeters long and each had approximately a one inch root in length. The general condition of the plantlet was good.

As the seedlings were selected from the germinator they were imrediately placed in position in the experimental 
vessels. When the selection was completed, the vessels containing the seedliness were set aside for a period of twenty-four hours. This time was allowed for general adaptation of the sprouts.

Each dish of plantlets was numbered so that each group was easily distinguished, 1. e., it, \#2, \#3, and control. Each experimental dish was exposed to rays of wave 'lengths 1349 A to 3900 A at a distance of 30 inches from the mercury quartz arc. Plant group number 1 was exposed three minutes, number $2 \mathrm{~s} 1 \mathrm{x}$ minutes, and number 3 ten minutes. Four exposures were made. On the day following the fourth exposure of the seedings pliotographs of each group were taken, (Figs.1, 2, 3, and 4). which show the development of the seedlings at this stage. The planto subjected to the ultra-violet rays were superior in size and vigor to the control and displayed a much greater leaf surface. The stem of the irradiated groups were also mush greener and thicker.

Experiment 2.

January 4, 1930, a second experiment was started under the same conditions as experiment number one and for the same experimental period. The day following the 


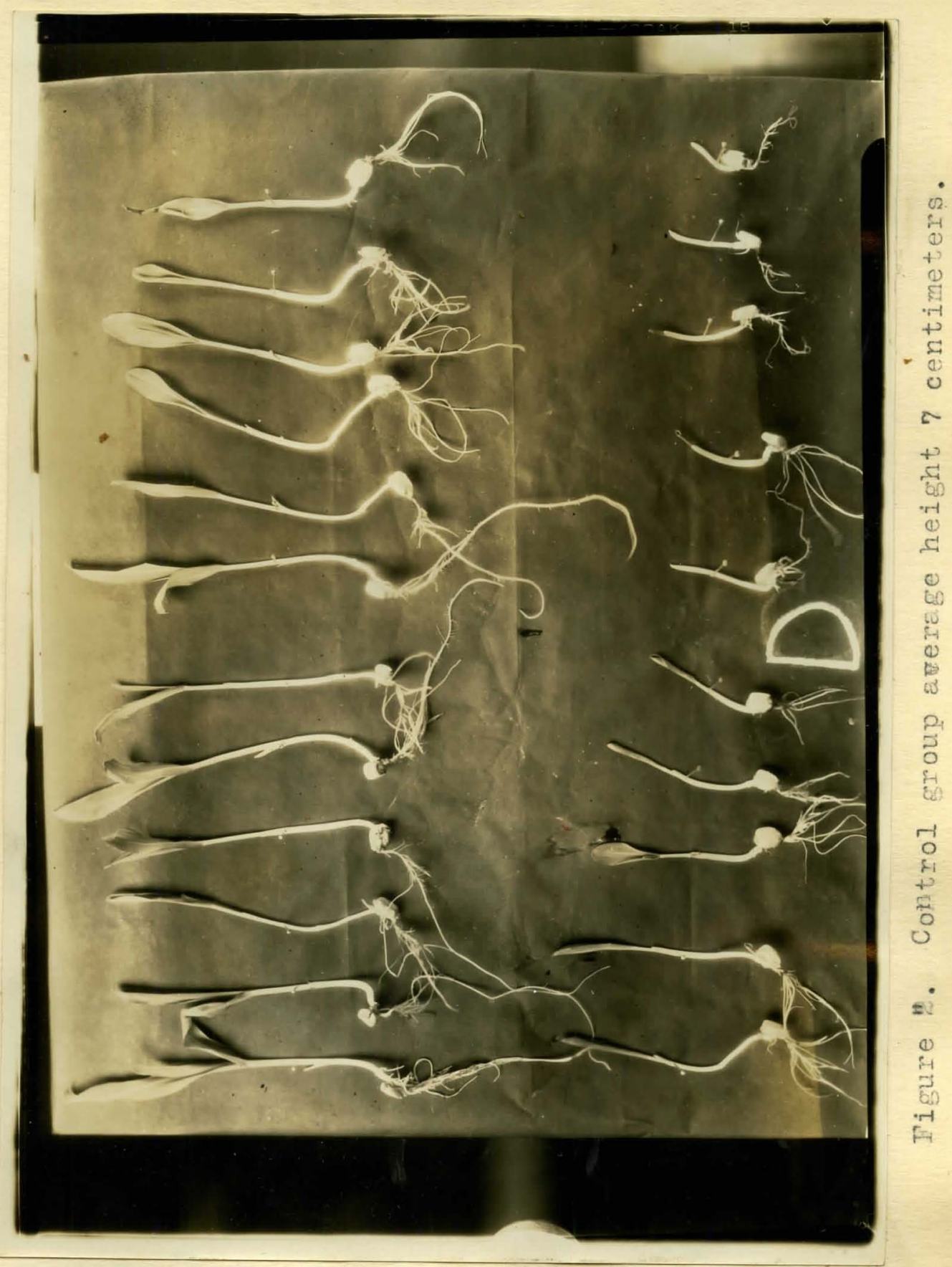




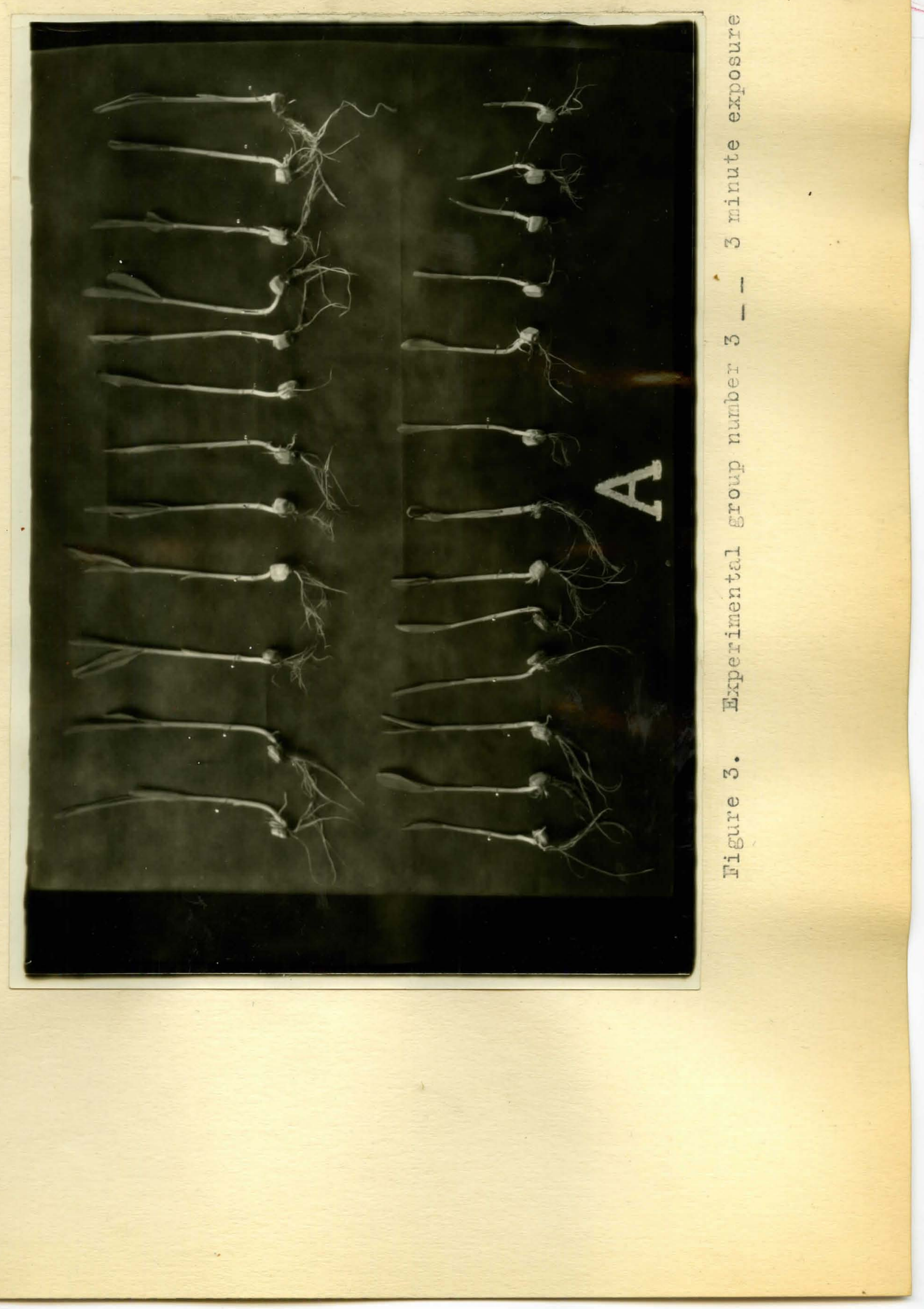




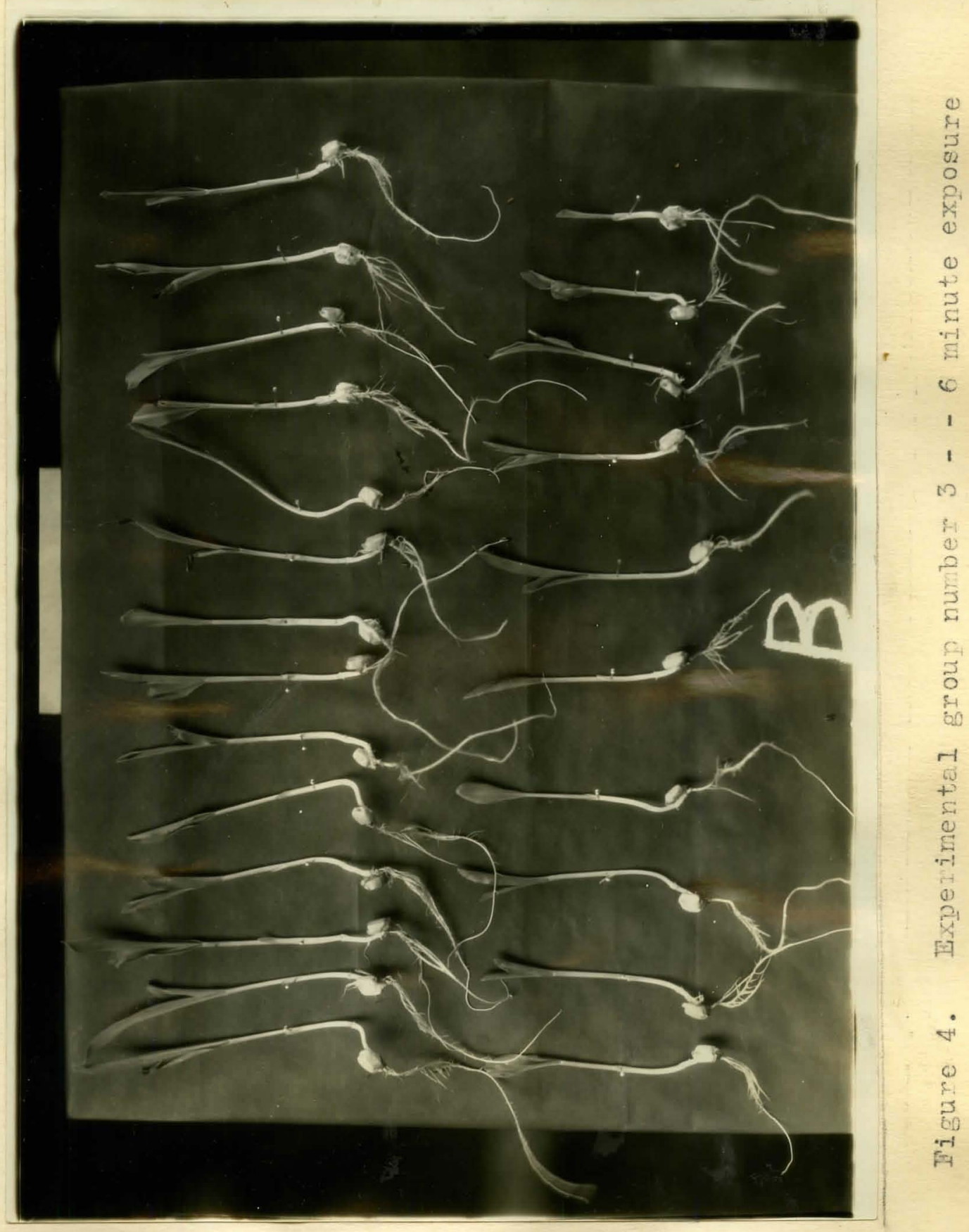




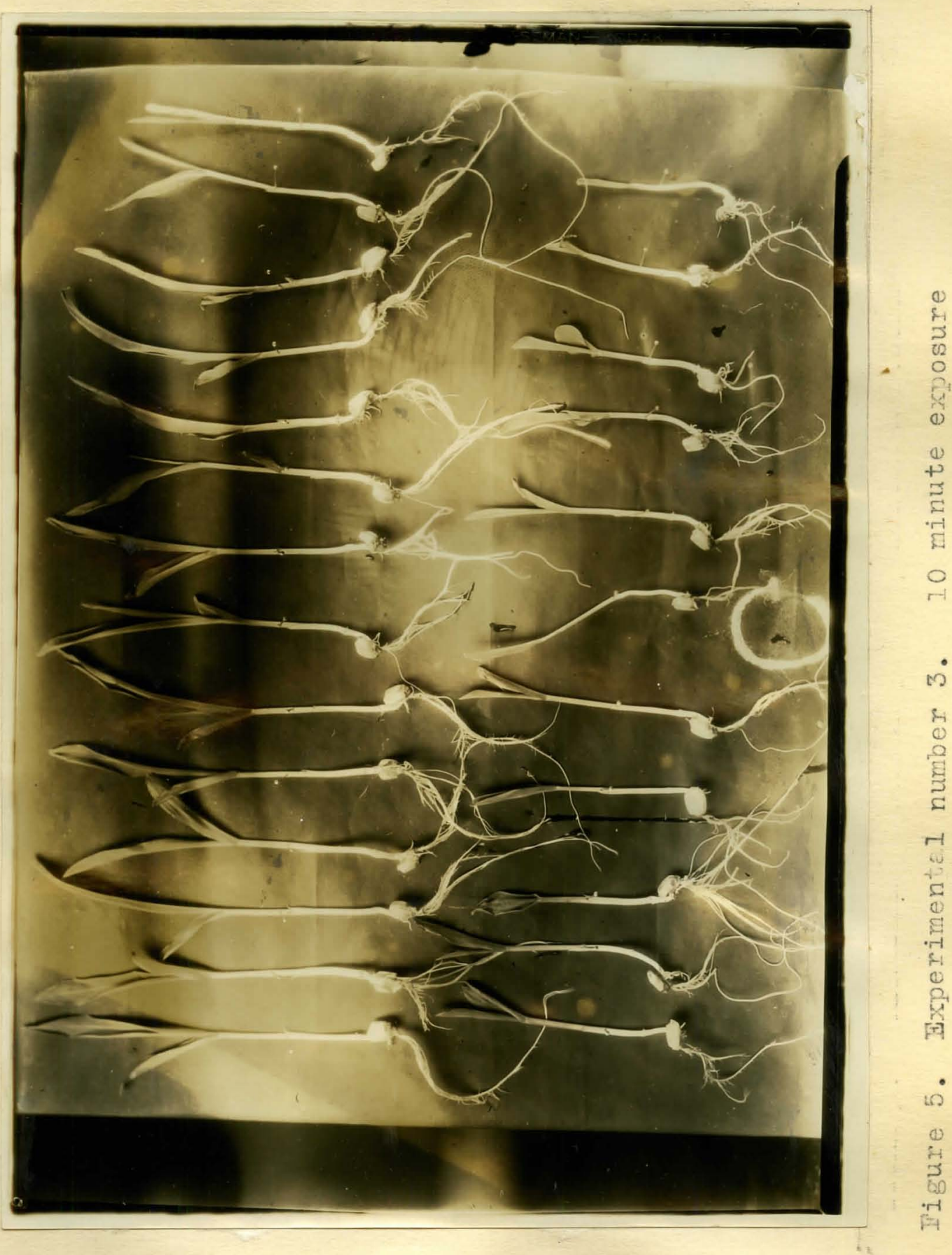


Second Experiment - -4 Exposures Plant Ht. Cra. Ht. Cm Ht. Cn Ht. Cm. No. Control 3 min. 6 min. 10 min.

\begin{tabular}{|c|c|c|c|c|}
\hline $\begin{array}{l}1 \\
2 \\
3\end{array}$ & $\begin{array}{r}13.0 \\
13.0 \\
8.5\end{array}$ & $\begin{array}{r}10.3 \\
9.8 \\
10.8\end{array}$ & $\begin{array}{l}9.4 \\
9.5 \\
8.9\end{array}$ & $\begin{array}{r}9.4 \\
3.2 \\
12.5\end{array}$ \\
\hline 4 & & 0.5 & 12.0 & 12.0 \\
\hline 5 & & 12.4 & 3.5 & 9.0 \\
\hline 6. & $\begin{array}{l}9.2 \\
4.0\end{array}$ & $\begin{array}{l}3.1 \\
7.6\end{array}$ & 11.3 & $\begin{array}{r}5.0 \\
11.5\end{array}$ \\
\hline ó & 4.2 & 3.1 & 3.2 & 13.5 \\
\hline 2 & 2.0 & 0.7 & 3.5 & 7.0 \\
\hline 10 & 5.0 & 8.2 & 8.7 & 12.2 \\
\hline 11 & 11.5 & 2.5 & 9.0 & 8.5 \\
\hline 12 & 4.0 & 6.5 & 9.0 & 12.5 \\
\hline 13 & 4.0 & 5.5 & 10.1 & 10.0 \\
\hline 14. & 2.0 & 9.0 & 10.5 & 12.7 \\
\hline 15. & 5.0 & 6.4 & 9.6 & 10.5 \\
\hline 16 & 12.0 & 0.4 & 7.3 & 11.0 \\
\hline 17 & 7.5 & 12.4 & 2.0 & 10.2 \\
\hline 13. & 6.0 & 5.5 & 7.2 & 11.1 \\
\hline 10 & & 10.6 & 0.5 & 10.2 \\
\hline 20 & 2.5 & 5.5 & 10.2 & 12.5 \\
\hline 21 & 11.8 & 5.0 & 9.0 & 11.0 \\
\hline 2 & 7.5 & 4.5 & 3.5 & 12.0 \\
\hline 23 & 3.0 & 9.5 & 1.5 & 10.2 \\
\hline 24 & 11.5 & 7.2 & 5.4 & 2.5 \\
\hline 25 & 10.0 & 2.1 & 13.2 & 6.5 \\
\hline
\end{tabular}

$\begin{array}{lllll}\text { Total } & 158.2 & 199.0 & 217.2 & 262.8\end{array}$

$\begin{array}{lllll}\text { Averate } & 7.2 & 3.0 & 8.7 & 14.8\end{array}$




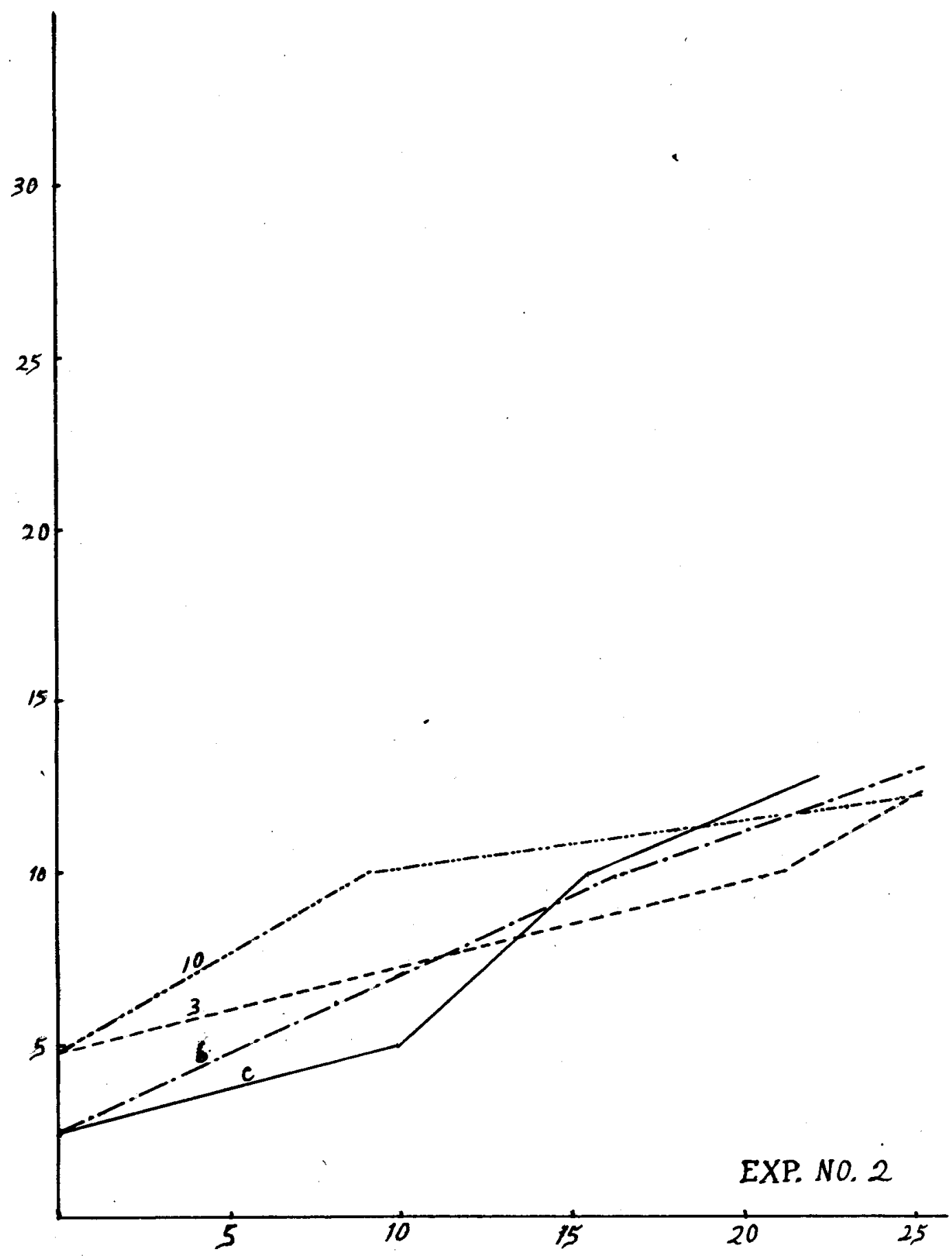

FIG. 6. 
fourth exposure to the ultra-violet rays, measurements of the seedlings were taken. In this experiment the helght only was taken. The result 18 given in the following table.

In this experiment each group correspond closely to those of the preceeding experiment.

The control average helght was $7.2 \mathrm{~cm}$; that of the group subjected to three minute exposure was 8. cm.; that of the group subjected to six minutes exposure was $9 . \mathrm{cm}$. ; and that of the group subjected to ten minutes exposure 14. cm.

Table shows the helght attained by each individual seedling. Figure is a graph of tine distribution of these seedlings as to the height.

EXPERIMENT 3.

Experiment number 3 was prepared and conducted in the same manner as nunber 2 except that the experimental groups were exposed to the ultra-violet light seven times instead of four. The experiment appeared quite comparable in every way to the preceeding experiment up to the fourth exposure. It was quite noticable from this stage on that the control tems lengthened more rapidly than the experimental. The tems of the control were more slender and 
Third Experiment Seven Exposures

Plant ControlHt.Cm. Ht. Cr. Ht.Cm. Dialtil. Dia.Mm.Dia.Lm. Dia.Mm No. Ht. En. $3 \mathrm{~min}$. $6 \mathrm{~min} 10 \mathrm{~min}$ Control $3 \mathrm{~min} 6 \mathrm{~min} 10 \mathrm{~min}$

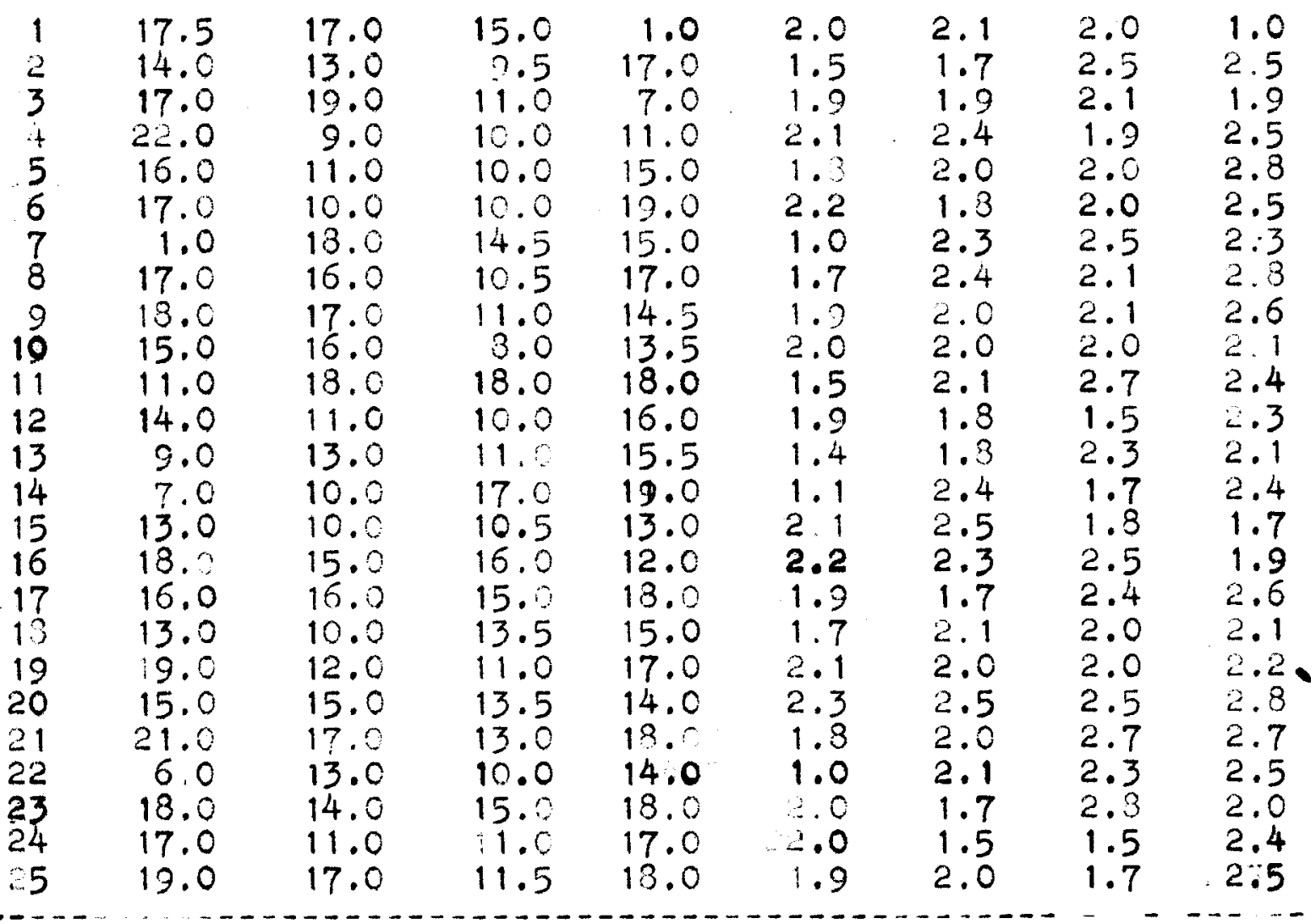

$\begin{array}{lllllllll}\text { Total } & 370.5 & 343.0 & 505.0 & 372.5 & 45.0 & 50.0 & 52.8 & 57.6\end{array}$ $\begin{array}{lllllllll}\text { Average } & 14.8 & 13.9 & 12.2 & 14.9 & 1.8 & 2.0 & 2.1 & 2.3\end{array}$

Figure 6 


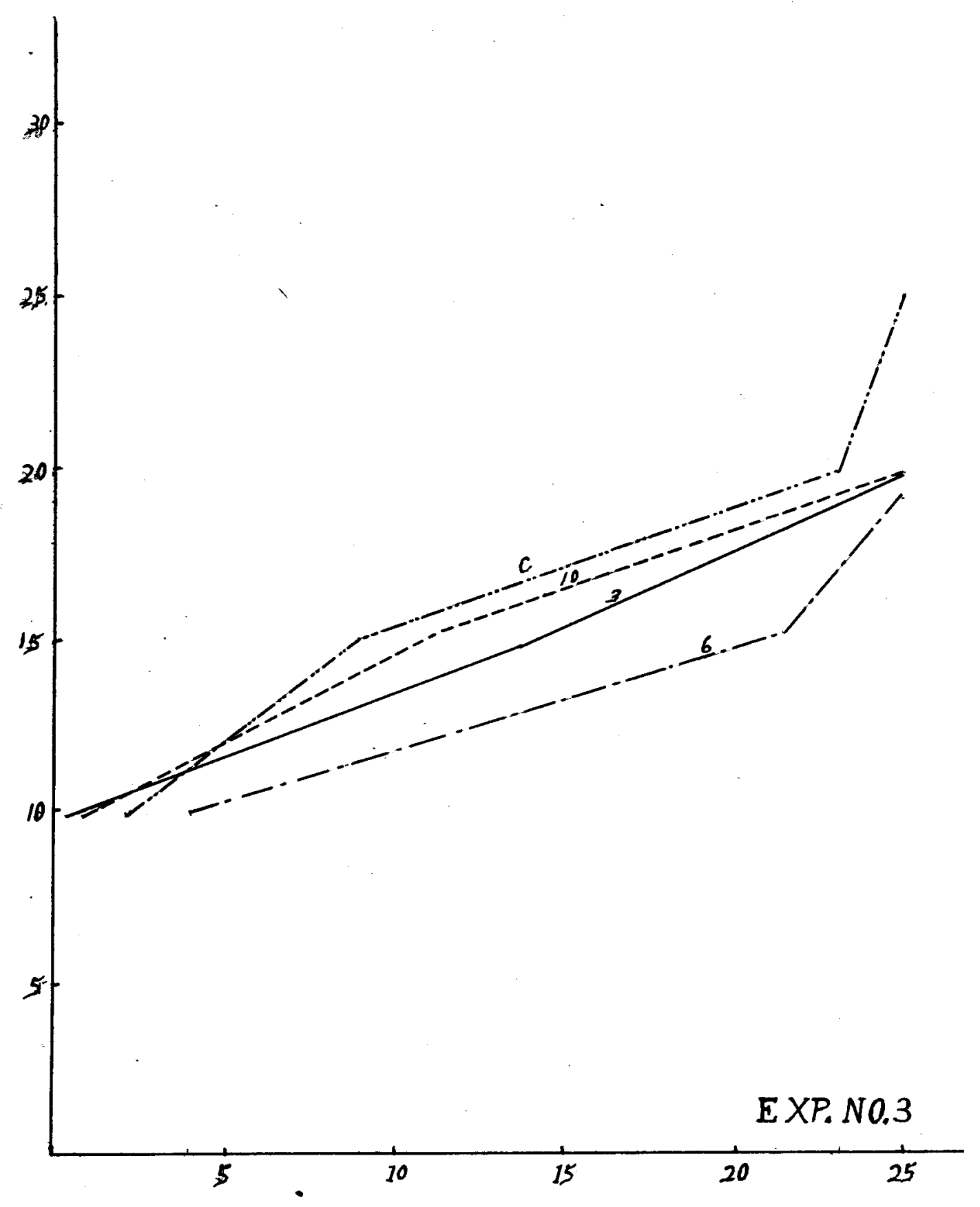

FIG 7 
feak. In rany instirces ther ware unable to stand erect. Dane (14) found the stems oi the irraiated plants were approximately one and one-half times es large in ciameter as the controi plants.

Experiment 4 .

The materials and methods wore the same as for previous experiments except thet eight exposures wore giren. Te found it imractical to give a greater numer. of Irraciations since accirate data was not easily obtained from older and longen sealings. The etens of the control becane bent anc twisted anc inceed the se alings of all groups inclined to iall since there were no holdiasts for the woots, probaily aue to the increase in weight of the aerial portion of the jents. Generel comparison was more easily mace at this or carlier stages of developent. We found as a result of the exveriment that the irracisted jlants cortirived to show muck rore vigor, more especially in the ter rinute exposume. The leaf surfoce wes greater; the internodes were shortor and thicker and the entixe lant above the finst rode gove a thrifty Ereen appe ance $2 s$ though it had been cutivated under normal sumer conditions. 
Fourth Jiperiment Eisht Exposures

Plant Ht. Un. Ht. Cm. Ht. Um. Ht. CmDia. Hit. Dta.um.Dia.Mm.Dia.um iro. Cont. $3 \mathrm{~min} .6 \mathrm{~min} .10 \mathrm{~min}$. Cont. $3 \mathrm{~min} .6 \mathrm{~min} .10 \mathrm{~min}$

\begin{tabular}{|c|c|c|c|c|c|c|c|c|}
\hline $\begin{array}{l}1 \\
2 \\
5 \\
4 \\
5 \\
6 \\
7 \\
8 . \\
9 \\
10 \\
1 \\
12\end{array}$ & $\begin{array}{l}20 \\
15.2 \\
22 . \\
23.5 \\
26.7 \\
13.7 \\
24.5 \\
21.5 \\
8.5 \\
22.5 \\
17.5 \\
12 .\end{array}$ & $\begin{array}{l}19.5 \\
13.5 \\
19.5 \\
9.7 \\
12.5 \\
18.5 \\
20.5 \\
20.5 \\
12.5 \\
14.5 \\
17.5 \\
13 .\end{array}$ & $\begin{array}{l}14 . \\
14 . \\
14.6 \\
15 . \\
15 . \\
15 . \\
16.5 \\
16.5 \\
17 . \\
19 . \\
15.2 \\
16 .\end{array}$ & $\begin{array}{l}14 . \\
21 . \\
15 . \\
18 . \\
16 . \\
17.5 \\
17.5 \\
18.5 \\
19.5 \\
15.5 \\
16.5 \\
21 .\end{array}$ & $\begin{array}{l}2.1 \\
1.9 \\
2.3 \\
2.5 \\
2.4 \\
1.1 \\
2.0 \\
1.6 \\
1.2 \\
2.0 \\
2.0 \\
1.5\end{array}$ & $\begin{array}{l}2.2 \\
1.9 \\
2.0 \\
2.3 \\
2.3 \\
1.7 \\
2.5 \\
2.6 \\
2.1 \\
2.5 \\
2.4 \\
2.2\end{array}$ & $\begin{array}{l}2.1 \\
2.0 \\
2.2 \\
2.1 \\
2.3 \\
2.7 \\
2.5 \\
2.9 \\
1.7 \\
1.8 \\
2.1 \\
2.5\end{array}$ & $\begin{array}{l}2.5 \\
2.8 \\
2.8 \\
2.3 \\
3.0 \\
3.0 \\
2.1 \\
2.0 \\
3.0 \\
2.5 \\
2.7 \\
2.4\end{array}$ \\
\hline $\begin{array}{l}13 . \\
14 . \\
15 \\
15 . \\
17 \\
13 \\
19 \\
29 \\
21 \\
22 \\
29 \\
24 \\
25\end{array}$ & $\begin{array}{l}25 . \\
20.5 \\
23.5 \\
25.2 \\
21 . \\
7 . \\
23 . \\
15 . \\
21.7\end{array}$ & $\begin{array}{l}13 . \\
9 . \\
15 . \\
18 . \\
18 . \\
22 . \\
21 . \\
16.4 \\
24 . \\
22 . \\
13.5 \\
26.0 \\
18 .\end{array}$ & $\begin{array}{l}15.5 \\
16.2 \\
13 . \\
15.5 \\
17.0 \\
15.0 \\
16.5 \\
17.5 \\
17.5 \\
17.5 \\
15 . \\
14.3 \\
11 .\end{array}$ & $\begin{array}{l}20 . \\
15 . \\
14 . \\
20 . \\
21.5 \\
18.5 \\
1.5 \\
17.5 \\
17 . \\
17.5 \\
20.5 \\
13.5 \\
7.5\end{array}$ & $\begin{array}{l}2.1 \\
2.3 \\
2.2 \\
2.2 \\
1.6 \\
1.7 \\
2 . \\
2.0 \\
2.0\end{array}$ & $\begin{array}{l}1.9 \\
2.0 \\
2.6 \\
2.7 \\
2.4 \\
1.9 \\
2.5 \\
2.7 \\
2.7 \\
2.0 \\
2.2 \\
2.1 \\
1.9\end{array}$ & $\begin{array}{l}2.1 \\
2.1 \\
2.0 \\
2.3 \\
2.5 \\
2.0 \\
2.7 \\
.5 \\
2.5 \\
2.3 \\
2.8 \\
2.7 \\
2.0\end{array}$ & $\begin{array}{l}2.2 \\
2.3 \\
2.5 \\
2.6 \\
2.2 \\
3.1 \\
2.0 \\
2.2 \\
2.2 \\
2.9 \\
2.1 \\
2.7 \\
2.0\end{array}$ \\
\hline
\end{tabular}

$\begin{array}{llllllll}\text { Total } 435.1 & 431.4 & 381.8 & 423.2 & 44.3 & 55.7 & 57.8 & 63.9\end{array}$

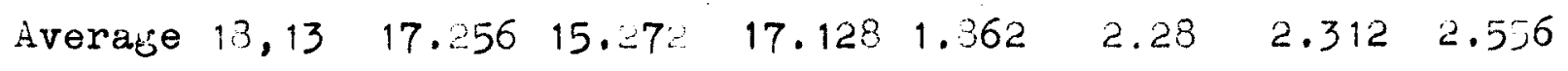

Pigure 8. 


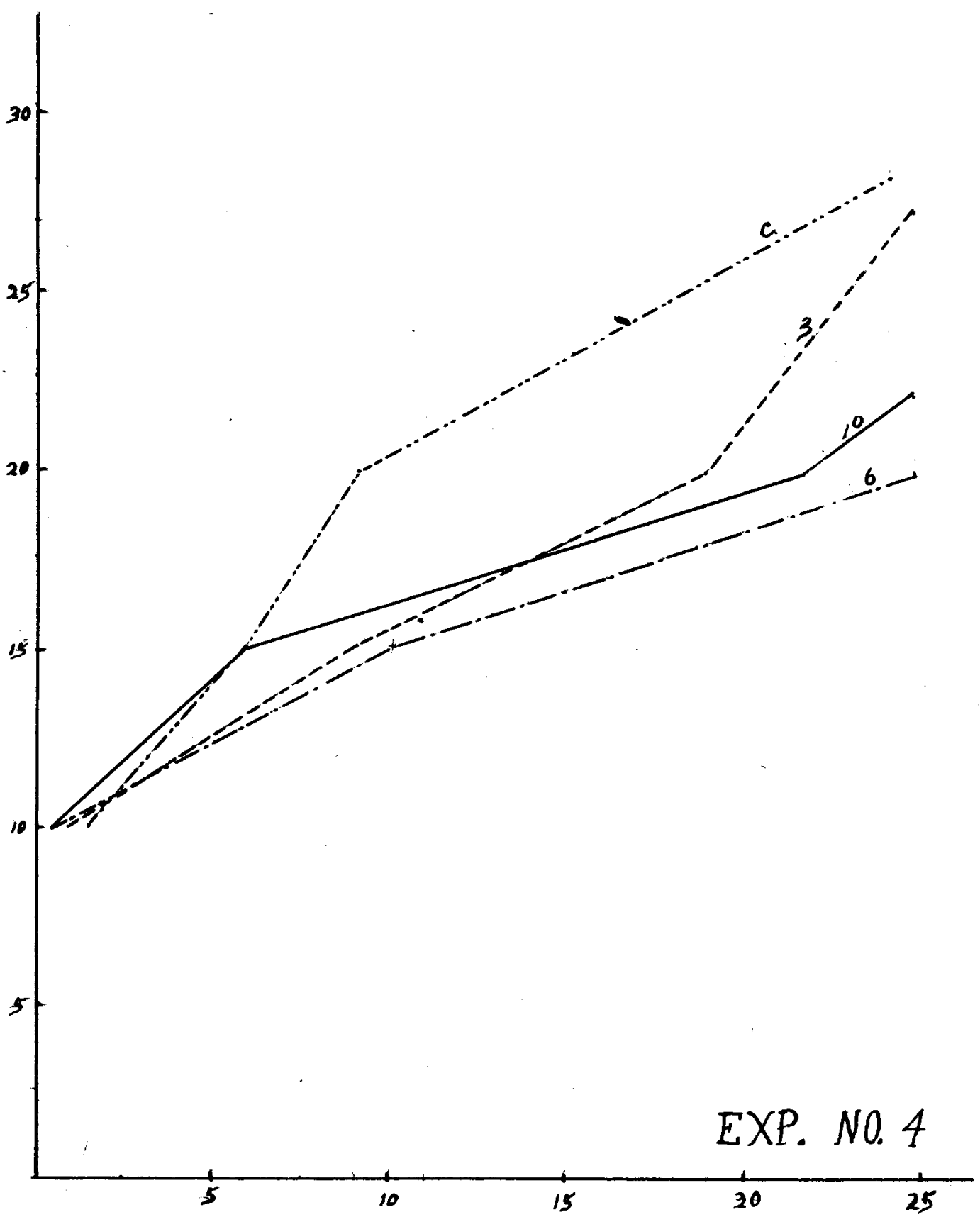

Fig. 9 
In table 3, measurement are given for the different groups. As shown by this table, the controls attained the greatest areage height, $1, e_{., 18.13 \mathrm{~cm} . ;}$ the three minute exposure, second, 1. e., 17.25. cm.; th ten minute exposure, third, $1 . e_{.}, 17.12 \mathrm{~cm} . ;$ and the $81 \times$ minute exposure was fourth, 1.e.,15.27 cm.

The diameters of the groups were as follows:

Average dlameter of control _................ $1.862 \mathrm{~mm}$. Average diameter of three minute exposure -..--.2.28 mm. Average diameter of s1x minute exposure -...-. $2.312 \mathrm{~mm}$. Average diameter of ten minute exposure -...-.- $2.556 \mathrm{~mm}$..

All measurement of dianeter were taken just above the firat node.

Experiments 5 and 6.

Experiments five and six were under the same conditions as experiment number four and exposures to ultra-violet rays were of the same duration.

The results of these experiments were very similar in every way to the preceeding one. The measurements in helght and diameter averaged very closely to the above P1gure.

Another characteristic which was common to the ten minute exposure was a purplish color of the stem. This was more prominent in some experiments than others. The 
Fifth Experiment Eight Exposures

Plant Control 3 ain. 6 in. 14 min Gontrol 3 aln. 6 min. 19 min No. Ht. Cm. Ht. Cm Ht. Cm Ht. Cm Dia, Um Dia.Mmpla, Mm. Dia.Mm

\begin{tabular}{rrrrrrrrr}
1 & 16.8 & 19.2 & 13.0 & 20.0 & 1.8 & 2.2 & 2.5 & 3.0 \\
2 & 19.0 & 28.5 & 15.0 & 20.0 & 2.5 & 2.0 & 2.1 & 3.0 \\
3 & 23.0 & 13.0 & 15.6 & 14.0 & 2.7 & 2.0 & 2.2 & 2.1 \\
4 & 21.0 & 21.0 & 14.0 & 15.2 & 2.0 & 2.7 & 2.1 & 2.1 \\
5 & 23.0 & 25.5 & 14.5 & 15.0 & 2.4 & 2.4 & 2.6 & 2.3 \\
6 & 15.0 & 16.4 & 15.4 & 17.0 & 1.2 & 2.0 & 2.7 & 2.8 \\
7 & 16.5 & 21.5 & 16.0 & 17.0 & 2.0 & 2.4 & 2.6 & 3.0 \\
3 & 18.0 & 21.5 & 16.0 & 18.5 & 1.7 & 2.7 & 2.6 & 2.3 \\
9 & 12.0 & 18.0 & 17.5 & 17.0 & 1.3 & 2.5 & 2.0 & 2.5 \\
10 & 21.0 & 18.5 & 3.0 & 13.0 & 2.0 & 2.7 & 2.0 & 2.8 \\
11 & 15.5 & 19.5 & 17.2 & 15.0 & 2.3 & 2.0 & 2.1 & 3.0 \\
12 & 24.5 & 4.0 & 15.2 & 16.5 & 1.7 & 1.6 & 2.0 & 2.0 \\
13 & & 13.0 & 16.0 & 15.5 & & 2.4 & 2.0 & 2.2 \\
14 & 15.0 & 12.0 & 15.5 & 21.0 & 1.3 & 2.0 & 2.3 & 3.0 \\
15 & 17.5 & 13.0 & 16.0 & 16.5 & 2.0 & 2.5 & 2.2 & 2.0 \\
16 & 15.2 & 18.5 & 13.5 & 16.5 & 1.0 & 2.0 & 2.1 & 2.6 \\
17 & 17.5 & 3.0 & & 23.0 & 1.9 & 2.6 &. & 2.2 \\
18 & 21.0 & 20.5 & & 22.0 & 2.1 & 2.7 & & 2.4 \\
19 & 12.0 & 12.5 & 15.0 & 19.0 & 2.0 & 2.0 & 2.5 & 2.3 \\
20 & 20.5 & 19.3 & 10.0 & 21.0 & 1.5 & 2.5 & 2.6 & 2.4 \\
21 & 21.0 & 20.5 & 16.5 & 20.5 & 1.1 & 2.5 & 2.6 & 2.4 \\
22 & 25.0 & 2.7 & 17.0 & 13.0 & 2.3 & 1.7 & 2.5 & 2.7 \\
23 & 17.3 & 19.5 & 13.0 & 13.5 & 1.8 & 2.6 & 2.5 & 2.3 \\
24 & 15.5 & 13.5 & 14.5 & 20.0 & 2.0 & 2.0 & 2.0 & 3.1 \\
25 & 9.0 & 19.5 & & 17.5 & 1.7 & 2.5 & 2.1 & 2.7 \\
\hline
\end{tabular}

$\begin{array}{lllllllll}\text { Total } & 439.8 & 435.1 & 319.5 & 439.2 & 46.9 & 57.2 & 52.8 & 63.3\end{array}$ $\begin{array}{lllllllll}\text { Average } & 18.32 & 17.4 & 14.52 & 17.56 & 1.95 & 2.28 & 2.29 & 2.53\end{array}$ 


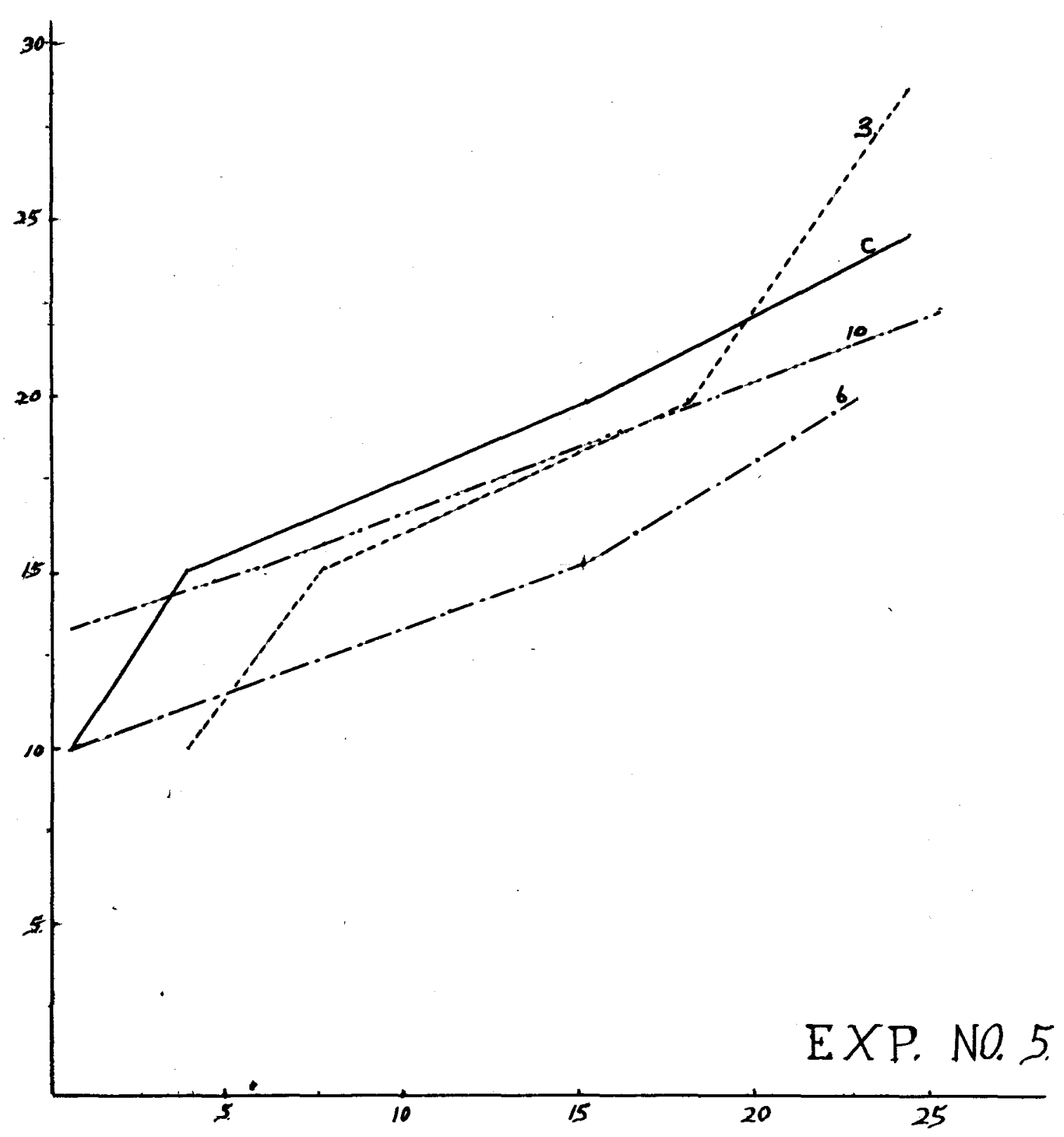

FIG. 11 


\section{Sixth Experiment Eight Exposures}

Plant Ht. Cr. Ht. Cm.Ht. Cm.Ht. Cm.D1a. Mm Dia. MmDia. Wm Dia.if

No. Control $3 \mathrm{~min} .6 \mathrm{~min} .10 \mathrm{~min}$. Control $3 \mathrm{~min} .6 \mathrm{~min} 1^{4} \mathrm{~min}$

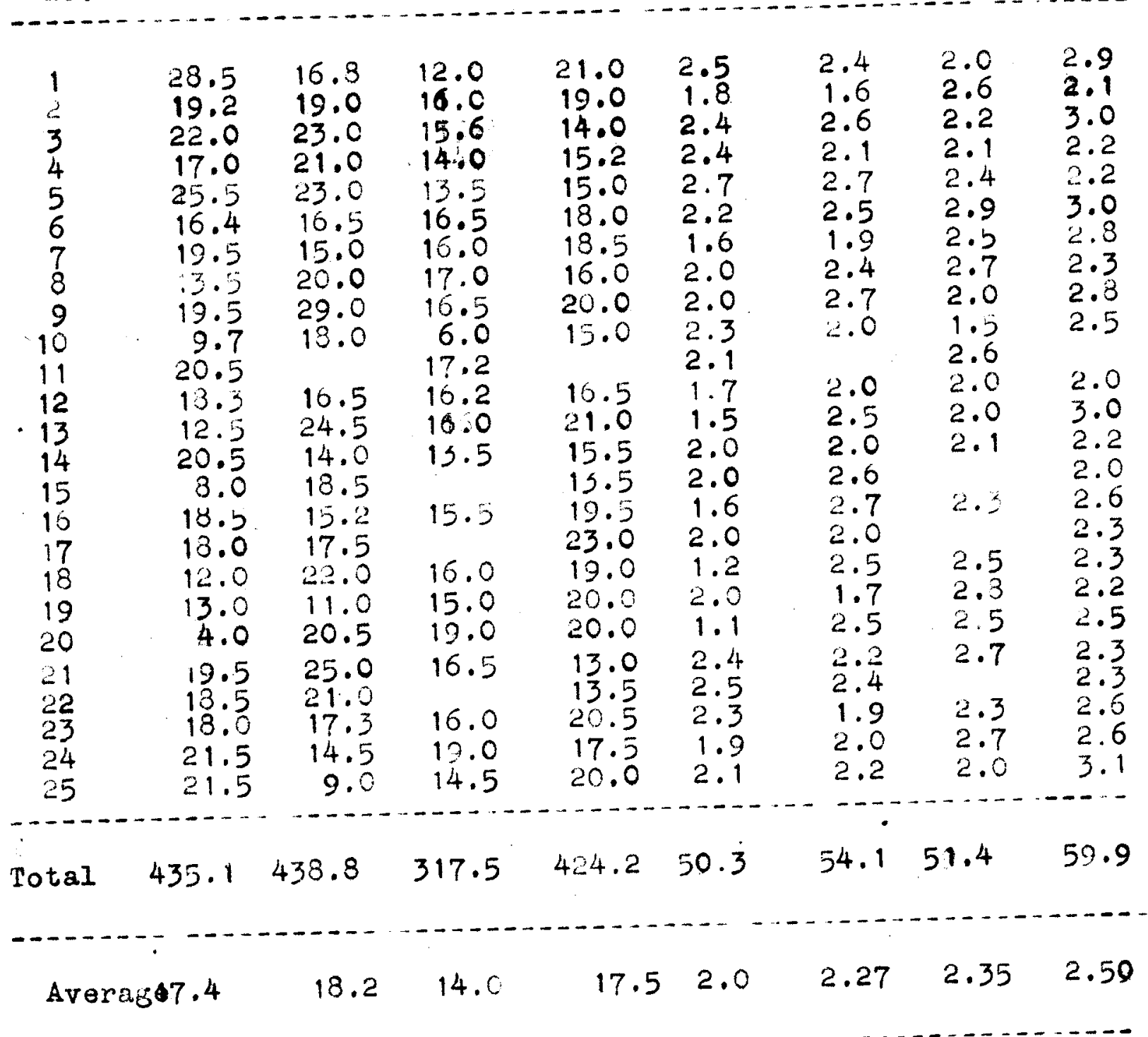


(20)

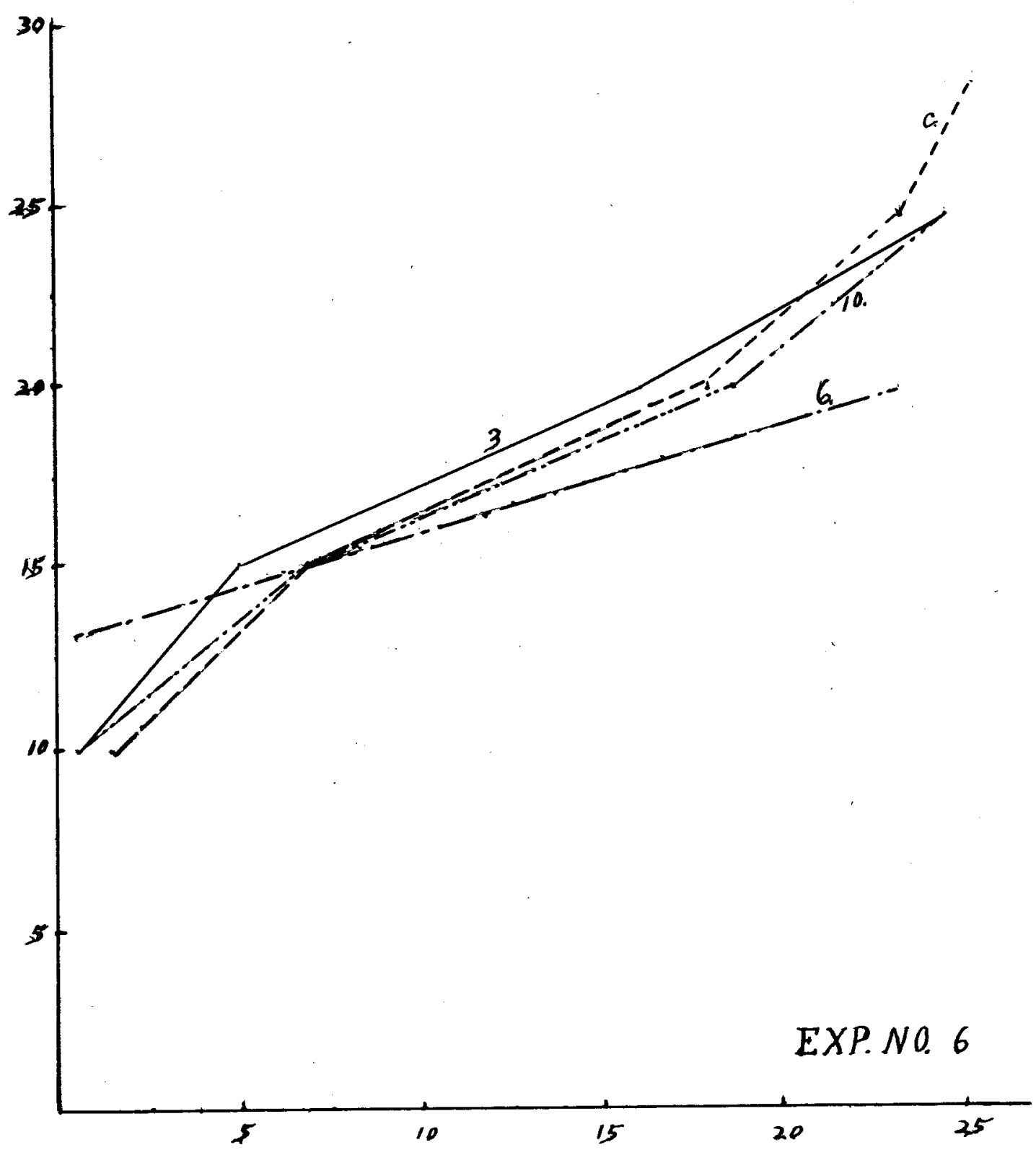

FIG. 13 
plarts, however, dic not seen less vigorous vecause of this tactor.

Tables four aria live Give the measurenents for these experinents, an the accompenying graphs show the curves for the heights of the various groups. 
SUMGARY AND CONCLUSION 
Sheard, Higging, and Foster (16) find the average height of stalks to be greatest in the infra-red and red red regions at the one extremity of the solar spectrum and in the violet and ultra-violet portions at the other extremity of the spectrum, and least under green and heat absorbing filters. Dane (4) finds that the diameter of plants are increased by exposure to ultra-violet rays. Experiments number one and two show that the exper1mental groups were longer and thriftier than the control. The general appearance of the 1rradiated groups wes normal, while the control gave the characteristic appearance of seedlings grown in diffused light.

In summarizing the general measurements and averages for all experiments under investigation, we find that;

In experiment number one the Irradiated groups were stimulated to an earlier growth and that the plants were larger and more vogorous throughout the experimental period.

In experiment number two, similar regults of the corresponding groups of experiment number one were obtained. 
The irradiated seedlings gave the appearance of a normal environment while those of the control group were spindling and lacked chlorophyll. The average height of the seedlings of the control group was 7.2 centimeters; that of the twenty-five seedings given ultra-violet radiations for three minutes dally during four consecutive days was 8.0 centimeters; that of the twenty-five seedlines given ultra-violet radiations for six minutes dally during four consecutive day was 8.7 centimeters; and that of the twenty-five seedlings irradiated for ten minutes daily during four consecutive days was 14.8 centimeters. The average height of the various groups of experiment number two were:

The control group of seedings averaged 7.2 cent1meters in height. The seedlings that were exposed three minutes averaged 8.0 centimeters in helght. Those for the $1 \mathrm{x}$ minute exposure averaged 8.7 centimeters in height, and those of the ten minute irradiation 14.8 centimeters in height.

In experiment three, seven exposures were given the experimental groups. The control of twenty-five seedlings had an average helght of 14.82 centimeters and an average 
diameter of 1.8 mililmeters. The twenty-five seedlings of the group given ultra-violet radiations measured 13.92 centimeters in helght and 2.0 millimeters in diameter. The twenty-pive seedlings of the group given six minutes exposure measured 12.22 centimeters In helght and 2.112 milimeters in diameter, and the twenty-five seedlings of the group given ten minute exposures measured 14.9 centimeter in height and 2.304 milimeters in diameter. In this experiment the control seedling grew more rapidly in height than the exposed seedlings during the latter part of the experimental period. The weak condition of the control continued in this experiment and the plants were unable to stand erect. In experiments numbers four, f1ve, and six the experimental groups were given daily exposures of the same duration as in the corresponding groups of the preceeding experiments, but they were given elght exposures instead of four or seven as in the earlier experiments. In exporiment number three, in which the experimental seedlings were exposed for seven consecutive days, the exposed seedlings underwent the same rate of development during the flrst four days of exposure as the corresponding groups of experiments 
numbers one and two, but during the lasr three days of exposare they increased more rapidly in diameter and did not elongate so rapidly as the control group. In experiments number four, number five, and number six this same phenomenon was observed, 1.e., the experimental seodlings underwent, during the firat four days of exposure, a development paralleling that of the corresponding seedilngs of experiments number one and number two, and during the fifth, sixth, and seventh day they underwent a development paralleling that of the corresponding seedlings during the corresponding days of experiment number three. During the eighth day of their exposure they continued to manifest the same developmental tendencies as those shown by them and by the experimental seodings of experinent number three during the days of exposure subsequent to the fourth. In other words, they elongated less rapidly than the control seedlings and increased more rapldiy than the control seedings in diameter.

The control seedlings of experiment four averaged 18.13 centimeterd in helght and 1.862 mililmeters in diameter. The group exposed three minutes daily averaged 17.256 centimeters in helght and 2.28 millimeters in diameter, The group exposed six minutes dally measured 15.272 centi- 
meters in heisht and $2.3: 2$ millimeters in diameter, and the group exposed ten minutes daily averaged 17.128 centimeters in helght and 2.556 millimeters in diameter. The plants of the group exposed ten minutes dally displayed a purplish color along the stem which had not been evidenced in previous experiments. The seedlings however, seemed quite as vigorous as normal seedlings. The plants were stalky, the internodes short and thick. The supporting tissue was abundant and turgesence was good.

Experiment number five. In this experiment the average meagurement were for the control group 18.325 cent1meters in helght and 1.95 millimeters in diameter; for the three minute exposed group 17.4 centimeters in height and 2.28 millimeters in diameter; for the six minute exposed group 14.52 centimeters in height and 2.29 millimeters in diameter; and for the ten minute exposed group 17.568 centimeters in height and 2.532 millimeters in diameter. This last group of seedlings gave every evidence of normal thrifty development as in the corresponding group of experiment four, and again the puppliah color of the stems was present. The root system of the various groups seemed to correspond with the aerial portions in length and diameter.

Experiment number six gave the same characteristics developed in experinents number four and number five. The 
average measurements were: for the control group 17.4 cent1metors in height and 2.0 millimeters in diameter; for the three minute exposed group 18.2 centimeters in height and 2.27 millimeters in diameter; for the group exposed six minutes 14 centimeters in helght and 2.35 millimeters in diameter; and for the group of seedlings exposed ten minutes 17.5 centlmeters in helght and 2.50 millimeters in diameter.

A general average of the measurements was computed for experiments number ftre and number $\mathrm{six}$ and were found to be as follows: the control group of seedings averaged 17.952 centimeters in helght and 1.937 millimeters in diameter. The group of seedings irradiated three minutes measured 17.608 centimeters in helght and 2.27 millimeters In diameter. The seedlings which had been exposed to the ultra-violet light for $81 x$ minutes measured 14.597 centimeters in helght and 2.317 millimeters in diameter; and those groups of seedlings which had been 1rradiated for ten minutes da1ly, measured 17.398 centimeters in height and 2.J27 m1111meters in diameter. The average measurements for the individual experiments and the general averages are contrasted in table below.

In the various groups of all experinents we observed that the gedings which were exposed ten minutes dally were 
- - - Averaje heljht - - 4 - - Averaje diameter - Cont. 3 min. $6 \mathrm{~min}$. $10 \mathrm{~min}$. Cont. $3 \mathrm{~min} .6 \mathrm{~min} .10 \mathrm{~min}$. Exp. $\begin{array}{lllllllll}4 & 13.130 & 17.256 & 15.272 & 17.128 & 1.362 & 2.28 & 2.312 & 2.556\end{array}$

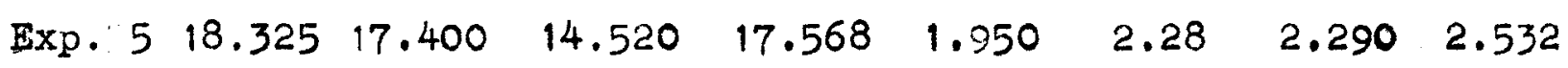

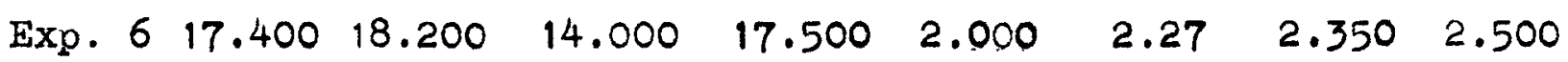

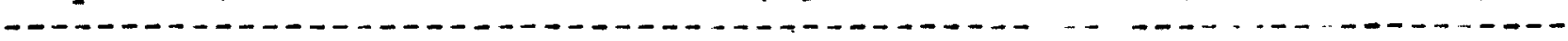

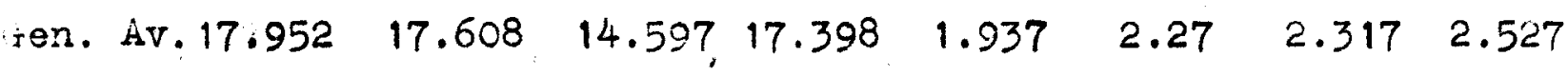

Table

quite superbor to any of the other groups. The plants were nore nearly uniform in size and quality. This reüularity of height wiale the average Ior this group about eival to that of the control regardiess of the fact that the control seedings Inclined to develop lons and slender stems.

the seedjiniss irradiated six minutes were shorter than the other groups but were very norual in ayedrance. The seedlings had a good leaf surface and thrifty olor and sten. The deedlings exposed three ininutes daily to the ultraviolet were not so thrifty in appearance as the plants which were subjected to longer exposures. The seedings appeared more spindling. The stens were not so green as those of the six or ten nimute groups, and the seedings seemed to lack supporting tissue. However it was easily observed that they 
were superior to the control group of seadings. They really seened to form a half way mark between the control seedings and the uroup of plants which were exposed ten minutes. In some of the experinents we took the wet and dry weighta of the different sroups. Generally the weichts were proportioal to the measurenents of the plants. There Beemed to be a slisit deviation from this in the experimental groups. The experimental seedings seemed to lose a higher percentage of inolsture from the wet to the ary weicht, than the seedings of the control group.

As far as the seedings of these experiments are concerned the following results were manifest:

1. Seedings of Zea maize grown in diffuse daylight are a Iinter green tian those that develop in direct sun11 int.

2. These seedlins also elongate more than those grown in sunligint and their stems lack supporting tissues. 3. Seedings frow the sane ear, when exposed daily for four consecutive days, at thirty inches from the mercury arc of a Burdick-Cooper-Hewitt lamp, to ultra-violet radiations of from $1849 \AA$ to $3900 \AA$ averaged greater in lengtin, were a darker green ani did not lack supporting tissues:

4. Seedings from the same ear, when exposed daily for seven or eight consecutive days, at thirty inches fron 
a Burdick-Cooper-Hewitt mercury arc lamp, to ultra-violet radiations of from $1849 \AA$ to $3900 \AA$ averaged shorter in length, were a darker sreen than the control group and those exposed for shorter periods dally had a purplish cast and developed neasurably sturdier stems.

j. In wet weight the experimental groupg uniformly everaged heavier than the corres onding groups.

6. When dried, the experinental sroupg lost more in weijit than the corresponding coitrol sroups.

7. The development of root systems corresponded closely in weight with that of the shoot in all the sroups, experimental and control.

3. Since the seedlings were all grown in tap water culture, the measurably greiter weight of the experinental seedings was probably due to a more rapidy absorption of the endosperm of the seed, and since the experinental seedlings lost wore welght through drying than did their controls, their greater weight was probably due to a Greater retention of water by their tissues.

9. Ultra-violet 11 gint of from $1349 \&$ to $3900 \&$ has functioned as a substitute for direct sunlisht in causing a more "nornal" development of the experimental seedings of these experinents than was shown by their controls grown in diffuse daylight. It 1s, therefore, 
probable thet it is these solar radiations that ar e principally responsible for the usual development of seediln;s. 

1. Bailey, L. H. Some preliminary studies of the influence of the electric arc lamp on green-house plants. Cornell Agl. Exp. Sta. Bull. 53: 145-157. 1893.

2. Bovie, W. T. and Hughes, D. H. Rate of recovery from action of fluorite rays. J. Gen. Physiol. 1: $323-329.1918$.

3. Bovie, T. T. Blophysics of ultra-riolet light. Boston Hed, and Surg. Jou. 2: 391-396. 1916.

4. Dane, H. R. The effect of ultra-violet radiation upon soy beans. Science N. S. 66: 80-81, 1927.

5. Ell1s, C, and Wells, A. A. "Chemlcal action of ultra-violet rays." Chemical Catalogue Co. N.Y. 1925.

6. Harvey, E. N. Fluorescence and inhibition in Ctenophores by ultra-violet light. Jou. Gen. Physiol. 1: $331-333.1925$.

7. Higgins, G. H., and Sheard, C. Germination and 
growth of seed as dependent upon selective irradiation. Plant Paysiol. 2: 325_335. 1227.

8. Jacob1, George. Action of ultra-violet on germination and growth. B10l. Abstracts \pm : 003 . 1930 .

9. Nacnt, D. I. Concernine the influence of polarized Ilitt on the jowth of sealines. Joun. of üen. Pr.sin 10: 41-52. 1926.

10. IcCrea, Adelia. Effecta of ultra-violet light upon Digitalis Purpurea. Science, N.S. 67: 277278. 1923.

11. McCrea, Adelia. The effect afon Digatilis Purpurea of radiation through solarized ultra-violet transmitting glass. Science N. S. 69: 628-629. 1929 .

12. McCrea, Adelia. Prolonged effect on Digltallo Purpurea of exposure under ultra-violet transmitting glass. Sc1emce N. S. 71: 346. 1930.

13. Middleton, A. R. Heritable variations and the result of selection in the f1ssion rate of Stylonychie Pustulata. Jour. Exp. Zool. \$9: 4-20. 1915. 
14. Rose, L. S. The effect of ultra-violet and infra-red rays upon the fisgion rate within a single clone of Paramecium caudatum and the heritability of that effect. Thesis - University of Louisville. 1929.

15. Sheard, C., and Higging, G. M. The influence of selective and general 1rradiction by quartz mercury arc lamp upon the germination and growth of seeds. Science N.S. 65: 282-284. 1927.

16. Sheard, C., Hijgins, G. M., and Foster, W. I. The jermination of seeds, growth of plants, and development of chlorophyll as influenced by selective solar 1rradiation. Sclence N. S. 71: 291_293. 1930.

17. Sherrd, C., and Johnson, A. F. The effect of Infrared visible and ultra-violet irradiation on changes in electrical potential and current in plants. Science N. S. 246-248, 1930 .

18. Shirley, H. L. The influence of light intensity and - light quality upon the growth of plants. Amer. Jour. Botany . 5: 355-388. 1929. 
19. Woodrow, J. W., Balley, A. C., and Fulmer, E. I. The effect of ultra-violet radiation upon jeast culture media. Plant Physiol. 2: 171-175. 1927. 